Pirineos, 153-154: 3 a 19, JACA; 1999

\title{
PRODUCTION AND TURNOVER OF ORGANIC MATTER IN THREE SOUTHERN EUROPEAN FAGUS SYLVATICA L. STANDS
}

\author{
I. SANTA REgINA ${ }^{*}$, S. LEONARDI ${ }^{* *}$, A. HANCHI ${ }^{* * *}$, T. TARAZONA $^{* * * *} \&$ M. RAPP TA* $^{* *}$ \\ * IRNA-CSIC, Cordel de Merinas, 37071 Salamanca (Spain). c.e.: ignac@gugu.usal.es \\ ** Facoltà di Scienze Matematiche, Fisiche e Naturali, Università di Catania, 19via A. \\ Longo, 95125 Catania (Italy). Corso di Laurea in Scienze Forestali ed Ambientali, \\ Università di Palermo, 23 via Roma, 92010 Bivona (Italy) \\ ***CNRS-CEFE, BP 5051, 34033 Montpellier Cedex (France) \\ ${ }^{* * * *}$ Servicio de Medio Ambiente. Junta de Castilla y León. Villar y Macías 1, Salamanca (Spain)
}

SUMMARY.- Above-ground biomass, litterfall and litter accumulation and decomposition at the soil surface were studied within three Mediterranean beech forests from Italy, France and Spain in order to better understand the recycling of elements associated with the turnover organic matter.

Above-ground tree biomass amounted to $131.9 \mathrm{Mg} \mathrm{ha}^{-1}$ at Etna (Italy), $134.2 \mathrm{Mg}$ ha ${ }^{-1}$ at Sierra de la Demanda (Spain) and $223.9 \mathrm{Mg} \mathrm{ha}^{-1}$ at Mont Lozère (France).

The highest amount of total litterfall was observed at Sierra de la Demanda (4.7 Mg ha ${ }^{-1}$ year $\left.{ }^{-1}\right)$, followed by the Mont Lozère (4.4 $\mathrm{Mg} \mathrm{ha}^{-1}$ year ${ }^{-1}$ ) and Etna $\left(3.9 \mathrm{Mg} \mathrm{ha}^{-1}\right.$ year $\left.{ }^{-1}\right)$.

Total organic matter accumulated on the soil surface in the three beech forests amounted to $25.8 \mathrm{Mg} \mathrm{ha} \mathrm{g}^{-1}$ at Mont Lozère, $14.4 \mathrm{Mg} \mathrm{ha}^{-1}$ at Sierra de la Demanda and $12.6 \mathrm{Mg} \mathrm{ha} \mathrm{s}^{-1}$ at Etna. The relative proportions of leaf litter versus total litter were nearly the same in the Etna and Sierra de la Demanda forests (72-70\%), and close to these values for Mont Lozère (65\%).

All the studied Mediterranean Fagus sylvatica stands appeared very similar concerning the organic matter distribution and fluxes, even if local climate and soil differences can be noticed.

RÉSUMÉ.- Les biomasses aériennes, les rètombées de litières, leur accumulation à la surface du sol et leur décomposition, ont été étudiées dans trois hêtraies méditerranéennes d'Italie, de France et d'Espagne, pour mieux connaître la restitution au sol des bioéléments par l'intermédiaire de la matière organique.

Les biomasses aériennes s'élevaient respectivement à $131.9 \mathrm{Mg}$ ha dans la hêtraie de l'Etna (Italie), $134.2 \mathrm{Mg} h a^{-1}$ dans celle de Sierra de la Demanda (Espagne) et à $223.9 \mathrm{Mg} \mathrm{ha}^{-1}$ au Mont Lozère (France). 
Les retombées de litière les plus fortes sont observées dans la hêtraie de la Sierra de la Demanda (4.7 $\left.\mathrm{Mg} \mathrm{ha}^{-1} a n^{-1}\right)$, suivie de celles du Mont Lozère (4.4 $\mathrm{Mg} \mathrm{ha}^{-1} \mathrm{an}^{-1}$ ) et de l'Etna (3.9 $\left.\mathrm{Mg} \mathrm{ha}^{-1} a n^{-1}\right)$.

L'ensemble de la matière organique accumulée à la surface $d u$ sol des trois hêtraies était de $25.8 \mathrm{Mg} \mathrm{ha}^{-1}$ au Mont Lozère, $14.4 \mathrm{Mg} \mathrm{ha}^{-1}$ à Sierra de la Demanda et $12.6 \mathrm{Mg} \mathrm{ha}$ dans l'Etna. Les proportions respectives de la fraction feuilles par rapport à la litière totale étaient proches dans les stations de l'Etna et de la Sierra de la Demanda (72 - 70\%) et voisines de celle du Mont Lozère (65\%).

Toutes les forêts de Fagus sylvatica dans le climat Mediterranéen sont très similaires par rapport à la distribution et aux flux, malgré qué les conditions de climat et de sol soient differéntes.

RESUMEN.- Se han estudiado la biomasa aérea, la caída, acumulación y descomposición de la hojarasca en tres ecosistemas forestales de hayedo en Italia, Francia y España en orden a conocer mejor el reciclado de elementos biógenos asociados al reciclaje de materia orgánica.

La biomasa aérea estimada es de $131.0 \mathrm{Mg} \mathrm{ha}^{-1}$ en Etna (Italia), $134.2 \mathrm{Mg} \mathrm{ha}^{-1}$ en la Sierra de la Demanda (España) y $223.9 \mathrm{Mg} \mathrm{ha}^{-1}$ en Mont Lozère (Francia).

La mayor cantidad de caida de hojarasca se ha observado en la Sierra de la Demanda (4.7 $\mathrm{Mg} \mathrm{ha}^{-1}$ año ${ }^{-1}$ ) seguida de Mont Lozère $\left(4.4 \mathrm{Mg} \mathrm{ha}^{-1}\right.$ año-1).

La materia orgánica acumulada en la superficie del suelo en los tres ecosistemas forestales estudiados fue de $25.8 \mathrm{Mg} \mathrm{ha}^{-1}$ en Mont Lozére, $14.4 \mathrm{Mg} \mathrm{ha}^{-1}$ en la Sierra de la Demanda y $12.6 \mathrm{Mg} \mathrm{ha}^{-1}$ en Etna. El pórcentaje relativo de las hojas con relación a la hojarasca total fue similar en las parcelas de Etna y Sierra de la Demanda (72-70\%) y algo más bajo en Mont Lozére (65\%).

Los bosques de Fagus sylvatica estudiados reflejaron valores similares respecto a la distribución y flujos de materia orgánica, aunque se han evidenciado diferencias en cuanto a condiciones locales de clima y suelo.

Key Words: Biomass, litterfall, litter decomposition, Fagus sylvatica.

Mots clés: Biomasse, retombée de litière, décomposition, Fagus sylvatica.

Palabras clave: Biomasa, caída de hojarasca, descomposición de las hojas, Fagus sylvatica.

\section{Introduction}

The biogeochemical cycle of organic matter and mineral elements plays a key role in the relationships between the soil, the vegetation and the surrounding environment. This cycle is one of the crucial ecological phenomena in natural biocenosis and, in particular, in forest ecosystems (RAPP, 1969). The most important contribution to the soil humus occurs through above-ground and root litter (GOSZ et al., 1976). Aboveground litter plays a fundamental role in the nutrient turnover and in the transfer of 
energy between plants and soil, being the source of the nutrient accumulated in the uppermost layers of the soil. This is particulary important in the nutrient budgets of forest ecosystems on nutrient-poor soils, where the vegetation depends in large part on the recycling of the nutrients contained in the plant detritus (SINGH, 1978, VOGT et al. 1986).

In forest ecosystem, litter production is mainly expressed as a massive contribution of dead organic matter that accumulates on the ground (MANGENOT \& TOUTAIN, 1980). This accumulated leaf litter on the soil surface, together with the contribution made by root decomposition (McCLUGHERTY et al., 1982), represents the basic source of energy, C, N, P, and other bioelements for the participating microflora and mesofauna of soil, as well as a quantity of easily available nutrients (RAPP \& LEONARDI, 1988).

The aim of the present work was to determine and compare distributions of above-ground living biomass and detrital biomass: litterfall and litter accumulation, in three Fagus sylvatica forests, under a Mediterranean climate, in Spain, Italy and France, differing nevertheless by local climate, soil characteristics, site history, topographical position, stand age and stand structure.

\section{Material and methods}

\subsection{Study sites}

Three Fagus sylvatica stands were selected in the Etna volcano (Italy), Sierra de la Demanda (Spain) and Mont Lozère (France), to compare different stand characteristics in a Mediterranean area (Figure 1).

All stands are located in mountain-Mediterranean climate involving cold winters and hot dry summers, with Mediterranean, maritime and mountain climatic influences.

The climate is meso-Mediterranean in the Etna volcano, with a mean annual temperature of $10^{\circ} \mathrm{C}$ and a mean annual rainfall of $660 \mathrm{~mm}$.

In Sierra de la Demanda, the climate is also meso-Mediterranean, becoming sub-Mediterranean with increasing elevation. Mean annual temperature and precipitation are $12.4^{\circ} \mathrm{C}$ and $895 \mathrm{~mm}$ respectively. The average length of the summer dry period is 2 months per year (July and August) and the length of the cold period (monthly average temperature less than $7^{\circ} \mathrm{C}$ ) is 6 months per year.

In Mont Lozère, the climate is mountain-Mediterranean, with a mean annual temperature of $6.5^{\circ} \mathrm{C}$. The mean monthly temperature limits were 


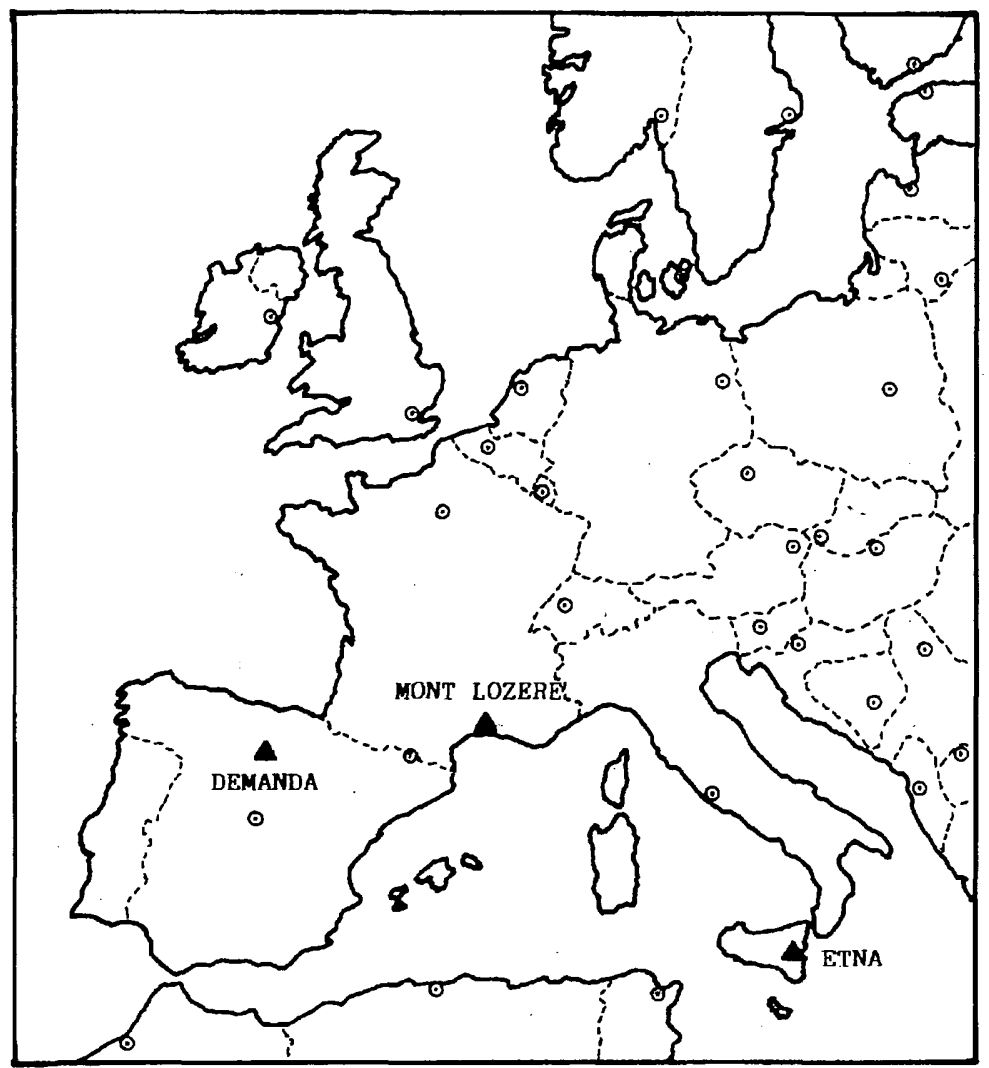

Figure 1. Situation of research sites on the Mediterranean area. Situación de las parcelas de experimentación en el área mediterránea.

obtained in August $1991\left(+17.4^{\circ} \mathrm{C}\right)$ and in December $1990\left(-2.3^{\circ} \mathrm{C}\right)$. There were more than 150 days with frost. Mean annual rainfall was $1431 \mathrm{~mm}$, with a very irregular distribution along the year, high rainfall levels in the autumn and spring, and long summer droughts. Snowfall contribution varied yearly, between $2.9 \%$ and $14.7 \%$ of overall precipitation.

The beech forest of the Etna volcano region is a naturally forest of over 45 years old, situated between $1450 \mathrm{~m}$ and $1750 \mathrm{~m}$ elevation, with a density of

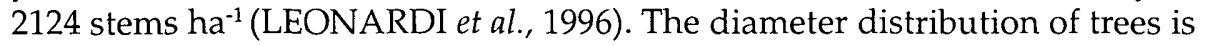
shown in Figure 2. The mean height ranged from 9 to $13 \mathrm{~m}$, and the basal area was $10.1 \mathrm{~m}^{\text {? ha }}{ }^{-1}$ (Table 1 ).

In Sierra de la Demanda, the beech stand is also a naturally forest, 50 years old, located at $1000 \mathrm{~m}$ over sea level, with a density of 523 trees ha ${ }^{-1}$ and tree 
PRODUCTION AND TURNOVER OF ORGANIC MATTER IN THREE SOUTHERN EUROPEAN.

\begin{tabular}{|lccc|}
\hline & Stem number $\left(\mathrm{ha}^{-1}\right)$ & Mean height $(\mathrm{m})$ & Basal area $\left(\mathrm{m}^{2} \mathrm{ha}^{-1}\right)$ \\
\hline Etna & 2124 & $9-13$ & 10.1 \\
Demanda & 523 & $20-22$ & 25.7 \\
Mont Lozère & 4271 & $7-8$ & 43.0 \\
\hline
\end{tabular}

Table 1. Stand characteristics of the three Fagus sylvatica forests.

Características de las tres parcelas de hayedo.

diameters ranging from 13 to $63 \mathrm{~cm}$. The diameter distribution classes are shown in Figure 2. The mean height ranged from 20 to $22 \mathrm{~m}$ and the basal area was $25.7 \mathrm{~m}^{2} \mathrm{ha}^{-1}$ (SANTA REGINA et al., 1996).

In Mont Lozère, the beech forest is nowadays naturally regenerated, after being planted at the beginning of the century. Uneven-aged between 50 and 80 years, the forest is located $1200 \mathrm{~m}$ above sea level. The density of this forest is 4270 trees ha-1. The diameter distribution classes are also shown in Figure 2. The mean height ranged from 7 to $8 \mathrm{~m}$ and the basal area was $43.0 \mathrm{~m}^{2} \mathrm{ha}^{-1}$ (HANCHI, 1994).

The soil from the Etna beech site is developed on basaltic lava and classified as Humic Andosol. The soil depth ranged from 20 to $40 \mathrm{~cm}$. HOFMANN (1960) indicates that the soil is poor in clay content with high sand (74\%) and lapilli (13\%) content, composed only by a dark A horizon, covering the lava substratum. The $\mathrm{pH}\left(\mathrm{H}_{2} \mathrm{O}\right)$ does not vary with depth and is around 6 .

At Sierra de la Demanda the soil is classified as Humic Acrisol. There are a wide range of soil depths, the clay content increasing with depth and the soil is developed on a paleozoic lithology. The $\mathrm{pH}\left(\mathrm{H}_{2} \mathrm{O}\right)$ is acidic, varying from 5.8 at the surface to 5.4 at $100 \mathrm{~cm}$ depth. The soil has a high organic matter content decreasing with depth from $15.9 \%$ to $3.3 \%$, with a $\mathrm{C} / \mathrm{N}$ relation around 20.0 at surface and 4.0 at depth.

The soil of Mont Lozère is a mountain ranker, developed on porphiroid granite (VANNIER, 1992). The soil depth ranges from 40 to $70 \mathrm{~cm}$. The $\mathrm{pH}$ $\left(\mathrm{H}_{2} \mathrm{O}\right)$ is acidic, varying from 4.6 at surface to 5.4 at $60 \mathrm{~cm}$ depth. The soil from Mont Lozère has a high organic matter content, with organic matter varying also, between 5 and $2 \%$ with increasing depth.

\section{Methods}

\subsection{Biomass determination}

We used allometric relationships between the biomass and the diameter at breast height $(\mathrm{DBH})$ of trees to estimate stand biomass: The $\mathrm{DBH}$ of all trees 
in plots of 1 hectare area was measured in each experimental site (1992) and diameter distributions calculated (Figure 2). Thirty representative trees of the different DBH classes were felled (13 in Italy, 7 in Spain and 10 in France) to establish above-ground biomass equations.

Each harvested tree was divided into stem, branches and leaves. Trunk sections, according to height $(0-1.3 \mathrm{~m}, 1.3-3 \mathrm{~m}, 3-5 \mathrm{~m}, 5-7 \mathrm{~m}, 7-9 \mathrm{~m}$ and so on), were weighed in the field along with total branch mass and individual branches. Subsamples for trunk, branch and leaf were brought to the laboratory for measurement of moisture content after drying to constant weight at $80^{\circ} \mathrm{C}$.

For each tree, trunk, branch and leaf dry mass and total dry biomass were calculated and correlated with DBH using regression analysis. Various regression equations, adjusted for the 30 sample trees, indicated the following determination coefficients: 0.679 for logarithmic regressions, 0.801 for exponential regressions, 0.968 for linear regressions and 0.984 for power regressions. The power regression equations: Biomass $(\mathrm{Kg})=\mathrm{a}\left(\mathrm{DBH}_{\mathrm{cm}}\right)^{\mathrm{b}}$,



Figure 2. DBH class distributions in the three studied Fagus sylvatica stands. Distribución por clases diamétricas de las tres parcelas de hayedo estudiadas. 
having the highest determination coefficients were used to estimate the total biomass of the different above-ground tree compartments.

Yearly wood production was estimated by dividing, for each stand, the above-ground perennial biomass by the mean age of the trees. This implies some approximations because of the doubts about the age of all trees from each stand, variations in production over the lifespan of the stands and death and disappearance of some trees during the same period.

\subsection{Litter fall}

Thirty litter traps, with $0.25 \mathrm{~m}^{2}$ interception area, were distributed randomly at the Spanish site and 28 at the French and Italian sites during a three years period (1990-1992). The litter traps were emptied monthly during autumn and the collected material was subdivided into leaves, reproductive material, wood and undetermined material, then oven dried to constant weight at $80^{\circ} \mathrm{C}$ and weighed. The results are expressed on a stand surface area (ha).

\subsection{Litter layer}

Accumulated total litter on the soil surface was estimated by collecting the organic layer (Aoo) from 15 samples $(0.5 \times 0.5 \mathrm{~m})$ in Spain, 16 in France and 12 samples $(0.25 \times 0.25 \mathrm{~m})$ in Italy, randomly chosen in all three stands. The inorganic $A_{h}$ layer was not included in these samples. Total litter was then dried and weighed.

The decomposition coefficient K of JENNY et al. (1949) was used to assess litter dynamics. It describes yearly litter decomposition in relation to humus type, above-ground litter and yearly litterfall. $\mathrm{K}$ is defined by:

$$
\mathrm{K}=\mathrm{A} /(\mathrm{A}+\mathrm{F})
$$

where $\mathrm{A}$ is the amount of litter returning annually to the soil, and $\mathrm{F}$ is the litter accumulated on the soil surface, before the period of massive litter fall (SANTA REGINA \& TARAZONA, 1995).

\section{Results}

\subsection{Above-ground biomass of Fagus sylvatica trees}

Power regression equations, calculated from the different samples of trees of the study are given in Table 2 . There were generally strong correlations 


\begin{tabular}{|lllcc|}
\hline Organs & stand & regression equation & tree number $n$ & correlation coefficient $r$ \\
\hline \multirow{5}{*}{ Stem } & Etna & $\mathrm{y}=0.118 \cdot x^{2.30}$ & 13 & $0.984^{*}$ \\
& Demanda & $\mathrm{y}=0.088 \cdot x^{2.47}$ & 7 & 0.962 \\
& Mont Lozère & $\mathrm{y}=0.106 \cdot x^{2.39}$ & 10 & 0.910 \\
& Three sites & $\mathrm{y}=0.107 \cdot x^{2.37}$ & 30 & 0.960 \\
Branches & Etna & $\mathrm{y}=0.040 \cdot x^{3.04}$ & 8 & 0.924 \\
& Demanda & $\mathrm{y}=0.033 \cdot x^{2.37}$ & 7 & 0.925 \\
& Mont Lozère & $\mathrm{y}=0.017 \cdot x^{2.58}$ & 10 & 0.896 \\
& Three sites & $\mathrm{y}=0.009 \cdot x^{2.77}$ & 23 & 0.883 \\
Leaves & Etna & $\mathrm{y}=0.002 \cdot x^{2.57}$ & 8 & 0.965 \\
& Demanda & $\mathrm{y}=0.016 \cdot x^{1.87}$ & 7 & 0.951 \\
& Mont Lozère & $\mathrm{y}=0.003 \cdot x^{2.32}$ & 9 & 0.943 \\
& Three sites & $\mathrm{y}=0.003 \cdot x^{2.42}$ & 23 & 0.921 \\
Total & Etna & $\mathrm{y}=0.138 \cdot x^{2.34}$ & 13 & 0.969 \\
& Demanda & $\mathrm{y}=0.131 \cdot x^{2.43}$ & 7 & 0.956 \\
& Mont Lozère & $\mathrm{y}=0.133 \cdot x^{2.40}$ & 10 & 0.911 \\
& Three sites & $\mathrm{y}=0.131 \cdot x^{2.40}$ & 30 & 0.945 \\
\hline
\end{tabular}

* The $\mathrm{P}$ value (significance of the regression coefficient is less then 0.01 ). / La significancin del coeficiente de regresión es menor de 0.01 .

Table 2. Relations established between above-ground biomass (y) and DBH (x) for each tree compartment and for the entire tree for the three stands studied. Relación entre la biomasa aérea $(y)$ y el $\mathrm{DBH}(x)$ para cada compartimento del árbol o para el árbol entero, todo ello en las tres parcelas estudiadas.

between biomass of the various components (trunks, branches, leaves) and DBH. As shown in Figure 3, the allometric relations between total biomass and DBH were very close for the three stands. This allowed us to calculate another regression, pooling the three stands. This last regression is not statistically different from that calculated for the Mont Lozère site.

From these results pooled regressions were also calculated for the aboveground biomass of Fagus sylvatica tree components. The relative proportions of foliage, branches and trunks in relation to $\mathrm{DBH}$ are shown in Figure 4.

Above-ground tree biomass amounted to $131.9 \mathrm{Mg} \mathrm{ha}^{-1}$ at Etna, $134.2 \mathrm{Mg}$ $\mathrm{ha}^{-1}$ at Sierra de la Demanda and 223.2 Mg ha-1 at Mont Lozère (Table 3). Although the amounts were very different between stands, especially between Mont Lozère and the two other sites, the proportions for the different tree compartments (leaves, branches and trunks) were very similar.

Foliage represented a relatively low proportion of total above-ground tree biomass. In the Etna stand, foliage amounted to 3.3\% (Table 3), very similar to the level in the Sierra de la Demanda stand: $3.2 \%$. In the Mont Lozère stand although leaf biomass was higher, the proportion of leaves to above-ground biomass amounted to only $2.1 \%$. 
PRODUCTION AND TURNOVER OF ORGANIC MATTER IN THREE SOUTHERN EUROPEAN...

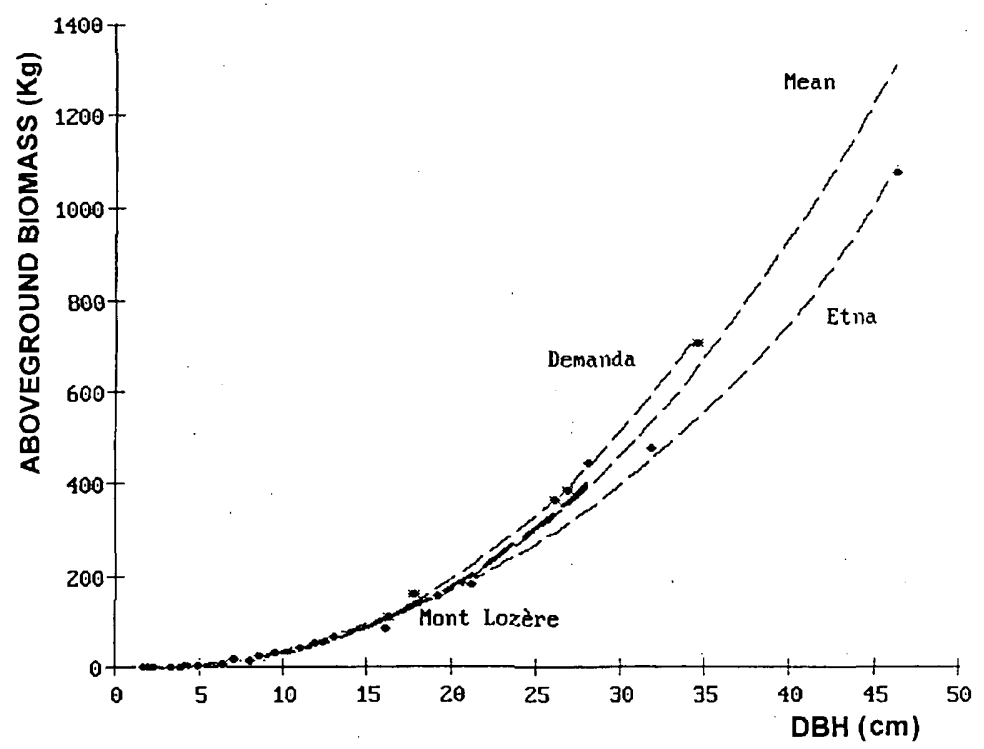

Figure 3. Regression curves for biomass $(\mathrm{Kg})$ in relation to $\mathrm{DBH}(\mathrm{cm})$ for the three stands and mean curve for Fagus sylvatica.

Curvas de regresión para la biomasa $(\mathrm{Kg})$ en relación con $s u D B H(\mathrm{~cm})$, para las tres parcelas y curva media para Fagus sylvatica.

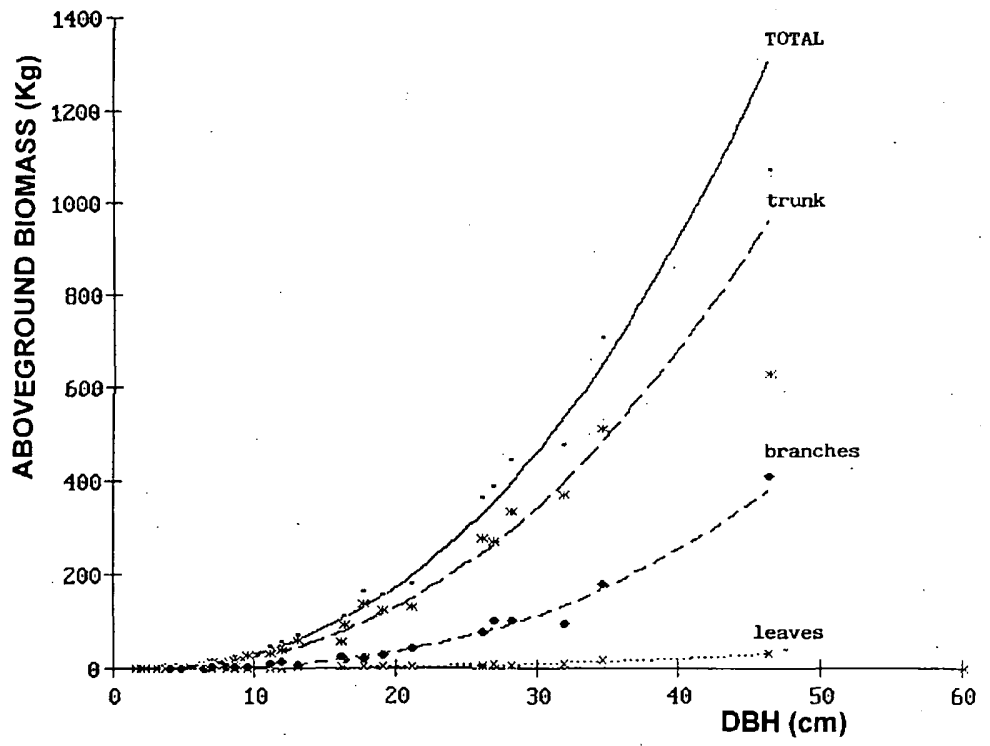

Figure 4. Relationships between $\mathrm{DBH}(\mathrm{cm})$ and biomass $(\mathrm{Kg})$ for different tree organs Relación entre el $D B H(\mathrm{~cm})$ y la biomasa $(\mathrm{Kg})$ en los diferentes órganos del árbol. 
PIRINEOS 153-154

\begin{tabular}{|c|c|c|c|c|c|}
\hline \multirow[t]{2}{*}{ Stand } & \multirow[t]{2}{*}{ Leaves } & \multicolumn{3}{|c|}{ Wood } & \multirow[t]{2}{*}{ Total above-ground biomass } \\
\hline & & Trunk & Branches & Total & \\
\hline Etna & $4.2 \pm 1.8$ & $100.3 \pm 19$ & $27.4 \pm 11$ & $127.1 \pm 26$ & $131.9 \pm 24$ \\
\hline Demanda & $4.2 \pm 1.5$ & $100.7 \pm 21$ & $29.4 \pm 12$ & $130.0 \pm 24$ & $134.2 \pm 25$ \\
\hline Mont Lozère & $4.6 \pm 1.7$ & $170.5 \pm 33$ & $48.1 \pm 16$ & $218.6 \pm 39$ & $223.2 \pm 40$ \\
\hline
\end{tabular}

Table 3. Biomass $\left(\mathrm{Mg} \mathrm{ha}^{-1}\right)$ of the three Fagus sylvatica stands. Biomaa $\left(\mathrm{Mg} \mathrm{ha} a^{-1}\right)$ en las tres parcelas de Fagus sylvatica.

Wood amounted to $97 \%$ of the above-ground biomass, and approximately $80 \%$ of this wood was from trunks and $20 \%$ from branches, with the following values for each stand: $76 \%$ trunk biomass and $20.8 \%$ branch biomass at Etna, and respectively $75 \%$ and $21.9 \%$ at Sierra de la Demanda, and $76.2 \%$ and $21.4 \%$ at Mont Lozère.

Mean yearly wood production in the 3 stands amounted respectively to 2.6, 2.8 and 4.4 Mg ha- ${ }^{-1}$ year $^{-1}$ at Sierra de la Demanda, Etna and Mont Lozère (Figure 5).

ETNA

(45) (Years)
DEMANDA

(50)
MONT LOZERE

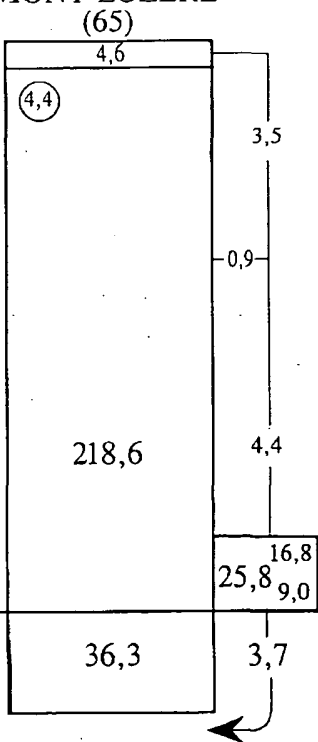

Figure 5. Organic matter distribution $\left(\mathrm{Mg} \mathrm{ha}^{-1}\right)$ and fluxes $\left(\mathrm{Mg} \mathrm{ha}^{-1}\right.$ year $\left.{ }^{-1}\right)$ within the three studied Fagus sylvatica stands.

Distribución de la materia orgánica $\left(\mathrm{Mg} \mathrm{ha} a^{-1}\right)$ y sus correspondientes flujos $\left(\mathrm{Mg} \mathrm{ha}^{-1}\right.$ año-1 - en cada una de las tres parcelas de Fagus sylvatica estudiadas. 
PRODUCTION AND TURNOVER OF ORGANIC MATTER IN THREE SOUTHERN EUROPEAN...

\subsection{Litterfall}

Table 4 summarizes annual litterfall for the three stands. The highest amount of total litterfall was observed at Sierra de la Demanda, followed by the Mont Lozère and Etna sites. The differences resulted more from wood, inflorescence and fruit litter, than from leaf litterfall. Leaf litterfall amounts were the highest with similar values at Etna and Mont Lozère.

The differences appearing between the estimated leaf biomass and the leaf litterfall are mostly related to the date of biomass sampling. Canopy leaf mass varies during the season. If the biomass is estimated in summer, at the peak of leaf growth, this could explain the differences with leaf litter amounts. In addition, leaf litter was sampled only from September to December, under estimating somé possible earlier leaf litterfall.

\begin{tabular}{|lccccc|}
\hline Stand & Leaves & Wood & Flowers-fruits & Other litter & Total litter \\
\hline Etna & $3.48 \pm 1.3$ & $0.07 \pm 0.01$ & $0.28 \pm 0.1$ & $0.05 \pm 0.01$ & $3.88 \pm 1.3$ \\
Demanda & $2.90 \pm 1.2$ & $0.82 \pm 0.02$ & $0.85 \pm 0.3$ & $0.11 \pm 0.50$ & $4.68 \pm 1.5$ \\
Mont Lozère & $3.46 \pm 1.3$ & $0.41 \pm 0.10$ & $0.41 \pm 0.3$ & $0.14 \pm 0.60$ & $4.42 \pm 1.4$ \\
\hline
\end{tabular}

Table 4. Yearly litterfall $\left(\mathrm{Mg} \mathrm{ha}^{-1}\right)$ within the three Fagus sylvatica stands. Caída de hojarasca anual $\left(\mathrm{Mg} h \mathrm{~h}^{-1}\right)$ en las tres parcelas de Fagus sylvatica.

\subsection{Litter accumulation on the soil}

Total organic matter accumulated on the soil surface in the three beech forests amounted to $25.8 \mathrm{Mg} \mathrm{ha}^{-1}$ at Mont Lozère, $14.4 \mathrm{Mg} \mathrm{ha}^{-1}$ at Sierra de la Demanda and $12.6 \mathrm{Mg} \mathrm{ha}^{-1}$ at Etna (Table 5). Although total organic matter accumulation varied markedly between the three stands, the relative proportions of leaf litter versus total litter accumulated were nearly the same in the Etna and Sierra de la Demanda forests (72 - 70\%), and close to the values in the Mont Lozère forest. $(65 \%)$.

\section{Discussion}

Figure 5 summarises the above-ground organic matter compartments and fluxes at the three studied sites; the amounts of annual wood production and annual litter decomposition have been added to this figure as well as an 
PIRINEOS 153-154

\begin{tabular}{|lccc|}
\hline Stand & Leaves & Other organic matter & Total \\
\hline Etna & $9.06 \pm 3$ & $3.58 \pm 1.3$ & $126.64 \pm 4.1$ \\
Demanda & $10.13 \pm 4$ & $4.32 \pm 1.4$ & $14.45 \pm 5.8$ \\
Mont Lozère & $16.82 \pm 5$ & $8.97 \pm 1.9$ & $25.79 \pm 7.6$ \\
\hline
\end{tabular}

Table 5. Litter accumulated on the soil surface $\left(\mathrm{Mg} \mathrm{ha}^{-1}\right)$ in the three Fagus sylvatica stands. Hojarasca acumulada sobre la suferficie del suelo $\left(\mathrm{Mg} \mathrm{ha}^{-1}\right)$ en las tres parcelas de hayedo.

\begin{tabular}{|c|c|c|c|}
\hline Stand & Wood biomass & Yearly wood production & Production \% biomass \\
\hline \multirow[t]{2}{*}{ Etna } & $127.7 \pm 27$ & $7.9 \pm 2.3^{*}$ & 6.2 \\
\hline & & $2.8 \pm 0.7^{* *}$ & 2.2 \\
\hline Demanda & $130.0 \pm 28$ & $2.6 \pm 0.6^{* *}$ & 2.0 \\
\hline \multirow{2}{*}{ Mont Lozère } & $223.2 \pm 46$ & $5.3 \pm 1.9^{*}$ & 2.3 \\
\hline & & $5.0 \pm 1.8^{* *}$ & 2.2 \\
\hline
\end{tabular}

estimation of the root biomass, calculated from values indicated by other authors and summarized in Table 7 . The mean value of $16 \%$ of above ground biomass was used for the estimation of root biomass is the three studied stands.

Mean annual wood production amounted to 2.6 and $4.4 \mathrm{Mg} \mathrm{ha}^{-1}$. At the Etna site, the $2.8 \mathrm{Mg} \mathrm{ha}^{-1}$ wood production determined for the total lifespan of the stand corresponded to a current production of $6.2 \mathrm{Mg} \mathrm{ha}^{-1}$, observed on the basis of the increase in DBH of all trees of the stand over 1 year (LEONARDI et al., 1996). At Mont Lozère, HANCHI (1994) found closer amounts with respectively $4.1 \mathrm{Mg} \mathrm{ha}^{-1}$ with the direct method (tree $\mathrm{DBH}$ increase during one year) and a mean value of $4.4 \mathrm{Mg} \mathrm{ha}^{-1}$ for the whole lifespan of the stand.

In all cases, mean productivity, expressed as percent of above ground perennial biomass, was similar for all tree Fagus sylvatica stands, with annual above ground perennial productivity of 2.0 to $2.2 \%$.

The $24.5 \%$ and $14.6 \%$ decomposition rates at Sierra de la Demanda and Mont Lozère, determined in the present study according to JENNY et al. (1949), could be compared to the decomposition rates of $29 \%$ at Sierra de la Demanda reported by SANTA REGINA \& TARAZONA, (1995) and to the $21.2 \%$ found at Mont Lozère (HANCHI, 1994), using only leaf litter at the litter-bag decomposition analysis technique. The lower decomposition rate 


\begin{tabular}{|c|c|c|c|c|c|c|}
\hline $\begin{array}{c}\text { Age } \\
\text { (years) }\end{array}$ & $\begin{array}{l}\text { Above ground } \\
\text { biomass } \mathrm{Mg} \mathrm{ha}{ }^{-1}\end{array}$ & 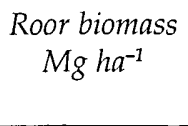 & $\begin{array}{l}\text { Root biomass } \\
\% \text { of above- } \\
\text { ground biomass }\end{array}$ & $\begin{array}{l}\text { Litterfall } \\
M g \text { ha }^{-1} \\
\text { year }\end{array}$ & $\begin{array}{l}\text { Net primary production } \\
\qquad \mathrm{Mg} \mathrm{ha}^{-1} \text { year }\end{array}$ & References \\
\hline 40 & 131 & 19 & 15 & & $3.0^{* *}$ & VYSKOT, 1989 a, b \\
\hline 45 & 132 & & & 3.9 & $\begin{array}{c}6.7^{*} \\
11.8^{* * *}\end{array}$ & LEONARDI et al., 1996 \\
\hline 50 & 134 & & & 4.7 & $7.3^{* * *}$ & SANTA REGINA et al., 1996 \\
\hline 50 & 145 & 35 & 24 & & $10.1^{* *}$ & BRUNO et al., 1973 \\
\hline $50-80$ & 224 & 33 & 15 & 4.4 & $\begin{array}{c}9.4^{*} \\
9.6^{* * *}\end{array}$ & HANCHI, 1994 \\
\hline 59 & 151 & 24 & 16 & 3.2 & $13.1^{* * *}$ & ULRICH et al., 1974 \\
\hline 80 & 155 & 22 & 14 & 3.3 & $10.0^{* * *}$ & ibid. \\
\hline 90 & 160 & 24 & 15 & 1.8 & & HALLBACKEN, 1992 \\
\hline 100 & 137 & 24 & 15 & 1.8 & & ibid. \\
\hline 122 & 271 & 30 & 11 & 3.1 & $11.0^{* * *}$ & ULRICH et al., 1974 \\
\hline 130 & 324 & 51 & & 5.7 & $8.6^{*}$ & NIHLGARD, 1972 \\
\hline 144 & 369 & 74 & & 3.5 & $12.2^{* * *}$ & DUVIGNEAUD et al., 1977 \\
\hline
\end{tabular}

Table 7. Comparison of biomass and productivity in several Fagus sylvatica stands. Net primary production $=$

* mean annual above-ground perennial increment + litter fall.

** only yearly increase in above-ground perennial material:

*** yearly increase in above-ground perennial material + litter fall.

Comparación de la biomasa y la productividad en varias zonas de Fagus sylvatica.

Producción primaria neta $=$

* media anual del incremento de biomasa perenne + caída de hojarasca.

** sólo incremento anual de la biomasa perenne.

*** incremento anual de la biomasa perenne + caida de horarasca. 
for total litter obtained according to JENNY et al. (1949), relatively to the litterbag data, was due to the presence of twigs and bark, rich in lignin (MEENTEMEYER, 1978) but with a lower nitrogen content (BERG, 1988).

In other beech forests, GLOAGUEN \& TOUFFET (1980) reported a decomposition rate of 25.6\%, calculated according to JENNY et al. (1949), while LEMEE \& BICHAUD (1973) obtained decomposition rates of 38.4\%, $31.1 \%$ and $39.5 \%$ for various beech stands. For other Fagaceae, BOCOCK (1963) indicated similar rates, while GALLARDO \& MERINO (1993) obtained lower rates.

The Etna and Sierra de la Demanda stands were very similar in terms of amounts of organic matter determined for the different tree compartments and in terms of fluxes. The Mont Lozère stand had higher biomass values and higher litter accumulation on the soil surface, while some fluxes, namely to litterfall and yearly litter decomposition, were close to the levels obtained at Sierra de la Demanda.

To compare the three sites, we calculated the different fluxes and organic matter compartments as a percentage of the above-ground perennial biomass for each of the three stands. The same picture was found between the Etna and the Sierra de la Demanda stands, with annual leaf production of 3.3\% and $3.2 \%$ of the perennial biomass, a mean annual increase of $2.2 \%$ and $2.0 \%$ of the perennial biomass and $3.0 \%$ and $3.6 \%$ litterfall, respectively. Annual decomposition of the litter layer amounted to $2.3 \%$ and $2.8 \%$ of the perennial above-ground biomass.

At Mont Lozère, the fluxes were lower, in relation to the higher aboveground perennial biomass:

$\begin{array}{ll}\text { leaf production: } & 2.1 \% \\ \text { litterfall: } & 2.0 \% \\ \text { litter decomposition: } & 1.7 \%\end{array}$

Only the mean annual increment of wood biomass $(2.0 \%)$ was the same as in the two other stands. Generally three factors could be responsible for these differences: stand age, soil and climate. The similarity between Etna and Sierra de la Demanda was probably more related to the age of the stands than to soil and climate patterns, which were very different. The differences between the Mont Lozère and the two other beech sites concern mainly leaf production and organic matter turnover.

In comparison to other Fagus sylvatica forests (Table 7), total above-ground biomass of the studied stands was closely correlated with the age of the trees, but such comparisons are hazardous. Indeed, total above-ground biomass varies also according to the geographical location, forest type, forest structure and degree of management or disturbance (BROWN et al., 1989). 
The three Mediterranean sites had very high amounts of litterfall, as compared to other Fagus sylvatica forests. Only the 130 year old beech forest studied by NIHLGARD (1972), showed a higher litterfall. However the ratio of the annual litterfall to above-ground biomass was lower than that determined in the three presently studied stands, indicating again a clear relation between stand age and leaf production.

\section{Conclusions}

There were similar levels (amounts and percentages) of organic matter production, accumulation and turnover in the three beech stands studied in France, Italy and Spain.

However the stands in Italy and Spain showed more similarities between them than with the French site. This latter site had higher amounts of aboveground biomes and litter, lower amounts for the main vegetation / soil fluxes: litterfall and litter decomposition, due perhaps, to its higher precipitation and mean annual temperature, or its different stand management and soil properties.

But all the three studied Mediterranean Fagus sylvatica stands appeared very similar concerning the organic matter distribution and fluxes, even if local climate and soil differences can be marked.

Acknowledgements: This project has been financed by C. E. and I. N. I. A. We thank the facilities given to us by the Environmental Service of J. C. L. in Burgos, Montpellier and Catania and in the same way to the ground staff who have collaborated in it. Our thanks go to N. Najac and C. Relaño for their technical help.

\section{References}

BERG, B. (1988). Dynamics of nitrogen (ISN) in decomposing Scots pine (Pinus sylvestris) needle litter. Long term decomposition in a Scots pine forest. Can. J. Bot., 66: 1539-1546.

BOCOCK, K. L. (1963). Changes in the amount of nitrogen in decomposing leaf litter of sessile oak (Quercus petraea). J. of Ecol., 55: 555-566.

BROWN, S., GILLESPIE, A. J. R. \& LUGO, A. E. (1989). Biomass estimation methods for tropical forests with applications to forest inventory data. For. Sci., 4: 881-902. 
BRUNO, F., MANES, F. \& GRATANI, L. (1973). Availability and cycling of nitrogen, phosphorus, potassium, calcium and magnesium in the beechwood ecosystem at Mt. Terminillo (Central Italy). Ann. Bot. (Rome), 32: $1-36$.

DUVIGNEAUD, P., KESTEMONT, P., TIMPERMAN, J. \& MONIQUET, J. C. (1977). La hêtraie ardennaise à Festuca altissima à Mirwart. Biomasse et productivité primaire. In: P. DUVIGNEAUD \& P. KESTEMONT (Eds.), Productivité Biologique en Belgique: 107-154. Duculot, Paris-Gembloux.

GALLARDO, A. \& MERINO, J. 1993). Leaf decomposition in two Mediterranean ecosystems of southwest Spain: influence of substrate quality. Ecology, 74: 152-161.

GLOAGUEN, J. C. \& TOUFFET, J. (1980). Vitesse de décomposition et évolution minérale des litières sous climat atlantique. I. Le hêtre et quelques conifères. Acta Oecol., 1: 3-26.

GOSZ, J. R., BORMAN, F. H. (1976). Organic matter and nutrients dynamics of the forest and forest floor in the Hubbard Brook forest. Oecologia, 22: 305-320.

HALLBÄCKEN, L. (1992). Long term changes of base cation pools and biomass in a beech and spruce forest of southern Sweden. Z. Pflanz. Bodenk. 155: $51-60$.

HANCHI, A. (1994). Cycle de l'eau et des éléments biogènes dans un bassin versant forestier: cas d'une hêtraie au Mont Lozère. Thèse Univ. Bourgogne, Dijon (France), $232 \mathrm{pp}$.

HOFMANN, A. (1960). Il faggio in Sicilia. Flora et Vegetatio Italica, 2, Sondrio (Italia), $235 \mathrm{pp}$.

JENNY, H., GESSEL, S. P. \& BINGHAM, F. T. (1949). Comparative study of decomposition rates of organic matter in temperate and tropical regions. Soil Sci., 68: 419-432.

LEMEE, G. \& BICHAUT, N. (1973). Recherches sur les écosystèmes des réserves biologiques de la forêt de Fontainebleau. II. Décomposition de la litière des feuilles des arbres et libération des bioéléments. Oecol. Plant., 8: 153-174.

LEONARDI, S., RAPP, M., FAILLA, M., GUARNACCIA, D. \& SIRACUSA, G. (1996). Cycle de la matière organique et gestion des bioéléments dans un peuplement de Fagus sylvatica de l'Etna. Ecol. Mediterranea, XXII, 3/4: 67-80.

MANGENOT, F., TOUTAIN, F. (1980): Les litières. In P. PERSON (Ed.) Actualités d'Ecologie forestière: 3-69 Gauthier-Villars. París.

McCLAUGHERTY, C. A., ABER, J. D., NELILLO, J. N. (1982). The role of fine roots in the organic matter and nitrogen budgets of two forested ecosystems. Ecology, 63: 1481-1490.

MEENTEMEYER, V. (1978): Macroclimate and lignin control of hardwood leaf litter decomposition dynamics. Ecology, 63: 621-626. 
PRODUCTION AND TURNOVER OF ORGANIC MATTER IN THREE SOUTHERN EUROPEAN.,

NIHLGARD, B. (1972). Plant biomass, primary production and distribution of chemical elements in a beech and planted spruce forest in south Sweden. Oikos, 23: 1, 69-81.

RAPP, M. (1969). Production de litière et apport au sol d'éléments mineraux dans des écosystems mediterranéens: La forêt de Quercus ilex $\mathrm{L}$. et la garrigue de Quercus coccifera L. Oecol. Plant., 4: 377-410.

RAPP, M. LEONARDI, S. (1988). Evolution de la litière au cours d'une année dans un taillis de chêne vert (Quercus ilex). Pedobiology, 32: 177-185.

SANTA REGINA, I. \& TARAZONA, T. (1995). Dynamics of litter decomposition in two Mediterranean climatic zone forests of the Sierra de la Demanda, Burgos, Spain. Arid Soil Res. E Rehab., 9: 201-207.

SANTA REGINA, I., TARAZONA, T. \& CALVO, R. (1996). Aboveground biomass in a beech forest and a Scots pine plantation in the Sierra de la Demanda area of northern Spain. Ann. Sci. For., 54: 261-269.

SINGH, K. P. (1978). Litter production and nutrient turnover in deciduous forest of Varanasi. Proc. Symp. Rec. Adv. Trop. Ecol., 655-665.

ULRICH, B., MAYER, R. \& HELLER, H. (1974). Data analysis and data synthesis of forest ecosystems. Göttinger Bodenkundliche Berichte 30: 1-459.

VANNIER, C. (1992). Les modalités de la rétention de soufre dans les sols de deux bassins versants forestiers du Mont Lozère. Thèse Univ. Orléans, 113 pp.

VOGT, K. A., GRIER, C. C.; VOGT, D. J. (1986). Production turnover and nutrient dynamics of above and below ground detritus of world forests. Advances in Ecological Research, 15: 303-377.

VYSKOT, M. (1989a). Nadzemni biomase mlade populace Buku lesniho. Lesnicivi 35, 6: 481-506.

VYSKOT, M. (1989b). Podzemni biomase mlade populace Buku lesniho. Lesnicivi 35, 7: 577-598. 